\title{
Lama Penyimpanan Daging Ayam Broiler Terhadap Kualitasnya Ditinjau Dari Kadar Protein Dan Angka Lempeng Total Bakteri
}

\author{
Insun Sangadji ${ }^{1}$, Jurianto ${ }^{2}$, Muhammad Rijal ${ }^{3}$ \\ ${ }^{1}$ Dosen Fakultas Peternakan Universitas Pattimura Ambon \\ ${ }^{2}$ Mahasiswa Program Studi Pendidikan Biologi, Fakultas Ilmu Tarbiyah dan Keguruan \\ Insistut Agama Islam Negeri Ambon \\ ${ }^{3}$ Dosen Program Studi Pendidikan Biologi, Fakultas Ilmu Tarbiyah dan Keguruan \\ Insistut Agama Islam Negeri Ambon \\ ${ }^{1}$ Email: insun_sangadji@gmail.com \\ ${ }^{3}$ Email: rijal_rijal82@yahoo.co.id
}

\begin{abstract}
Abstrak: Penelitian ini bertujuan untuk mengetahui pengaruh lama penyimpanan daging ayam broiler terhadap kualitasnya ditinjau dari kadar protein dan angka lempeng total bakteri. Penelitian ini dilakukan pada tanggal 11-19 Desember 2017. Rancangan yang digunakan dalam penelitian ini adalah Rancangan Acak Lengkap (RAL) dengan 3 perlakuan yang terdiri atas lama penyimpanan 2 hari (A1), 4 hari (A2) dan 6 hari (A3) dan jumlah ulangan sebanyak 3 ulangan. Data dianalisis menggunakan ANOVA. Analisis sampel dilakukan di laboratorium MIPA Fakultas Ilmu Tarbiyah dan Keguruan, IAIN Ambon dan Laboratorium Kimia Dasar Universitas Pattimura. Hasil penelitian menunjukkan bahwa terdapat pengaruh lama penyimpanan daging ayam broiler terhadap kadar protein dan angka lempeng total bakteri. Besar pengaruh lama penyimpanan daging ayam broiler terhadap kadar protein adalah 14,2\% sedangkan besar pengaruh lama penyimpanan daging ayam broiler terhadap angka lempeng total bakteri adalah $12,7 \%$.
\end{abstract}

Kata Kunci: Lama Penyimpanan, Daging Ayam Broiler, Kadar Protein, ALT

Abstract: This study aims to determine the effect of storage time of broiler chicken on its quality in terms of protein content and total bacterial plate number. This research was conducted on 11-19 December 2017. The design used in this study was a Completely Randomized Design (CRD) with 3 treatments consisting of 2 days of storage (A1), 4 days (A2) and 6 days (A3) and the number of replications is 3 replications. Data were analyzed using ANOVA. Sample analysis was carried out in the MIPA laboratory at the Faculty of Tarbiyah and Teacher Training, Ambon IAIN and Pattimura University Basic Chemistry Laboratory. The results showed that there was an effect of the length of storage of broiler chicken on protein levels and total bacterial plate numbers. The effect of broiler chicken meat storage on protein content was $14.2 \%$ while the effect of broiler chicken storage on the total plate number of bacteria was $12.7 \%$.

Key Words: Duration of Storage, Broiler Chicken Meat, Protein Levels, ALT

BIOLOGI SEL (VOL 8 NO 1 EDISI JAN-JUN 2019 ISSN 2252-858X/E-ISSN 2541-1225) PAGE 47 
Daging ayam merupakan salah satu bahan makanan yang bernilai gizi tinggi, karena mengandung protein dan asam amino esensial, lemak dari asam lemak esensial, vitamin dan mineral yang sangat baik untuk pertumbuhan manusia maupun perkembangbiakan mikroba. Ayam broiler mempunyai karakter ekonomis ditandai dengan pertumbuhan yang cepat menghasilkan daging yang mempunyai serat lunak, konversi pakan rendah dan siap dipotong pada umur yang relatif muda. Daging ayam broiler mudah rusak karena kontaminasi kuman yang berasal dari bulu, kulit, saluran cerna ayam maupun dari proses penyembelihan sampai dengan penyimpanan. Penyimpanan pada suhu refrigerator merupakan cara yang paling sederhana untuk mengawetkan dan memperpanjang masa simpan daging ayam broiler (Warsianti, 2008).

Daging ayam broiler yang diproses untuk penyimpanan jangka panjang dan untuk memenuhi permintaan daerah-daerah yang jauh, akan dikemas selanjutnya dibekukan. Pembekuan dilakukan untuk memperpanjang masa simpan, dengan tujuan membatasi aktivitas mikroorganisme, reaksi-reaksi enzimatik, kimia dan kerusakan fisik. Karkas utuh yang disimpan pada suhu $4{ }^{0} \mathrm{C}$ dapat tetap dalam keadaan baik selama tiga hari, sedangkan penyimpanan padasuhu $-32{ }^{\circ} \mathrm{C}$ dapatbertahan sampai satu tahun dan sembilan bulan untuk karkas yang dipotong-potong. Pembekuan komersial pada temperatur $-29{ }^{0} \mathrm{C}$ dan domestik pada $-18{ }^{0} \mathrm{C}$ merupakan metode standar preservasi dan produk dapat bertahan selama satu sampai dua tahun, tetapi selama penyimpanan dapat terjadi kemunduran kualitas dibanding daging segar atau dingin. Pembekuan mampu memusnahkan sebagian besar bakteri patogendan memperlambat atau menghambatpertumbuhan sejumlah mikroorganisme. Namun pembekuan tidakmembunuhsemua mikroorganisme dan tidak mengakibatkan sterilisasi makanan.Mikroorganisme banyak juga dapat bertahan hidup pada proses pembekuan dan bertumbuh setelah penyegaran kembali, apalagi bila jumlah mikroba awal tinggi. Pembekuan karkas atau daging juga tidak dianjurkan untuk waktu yang panjang karena dapat terjadi kemunduran kualitas daging (Dellen, 2011).

Kualitas daging ayam dapat ditinjau dari berbagai mutu. Sebagai bahan pangan, daging unggas tersusun atas komponen-komponen bahan pangan seperti, lemak, karbohidrat, vitamin, air, mineral pigmen dan protein. Protein adalah komponen bahan kering yang terbesar dari daging. Protein daging ayam disebut berkualitas tinggi, karena mudah dicerna, mudah diserap dan mengandung asam-asam amino esensial yang lengkap dalam jumlah yang besar dibandingkan dengan hewan lain di luar unggas (Hardjanto, 2006). Sedangkanayam broiler yang dipelihara pada umur 27 hari mempunyai protein daging sebesar 14,2\%, pada umur 42 hari sebesar 14\% dan pada umur 56 hari sebesar $13,9 \%$, dan menyimpulkan bahwa semakin bertambah umur ayam maka persentase protein dagingnya akan berkurang. Mutu dan keamanan daging ayam memegang peranan penting untuk memenuhi kebutuhan. Kualitas daging ayam meliputi kualitas fisik, kimia dan biologi serta diterima atau tidaknya oleh konsumen. Secara biologi kerusakan daging 
ayam lebih banyak diakibatkan oleh adanya pertumbuhan mikroba yang berasal dari ternak, pencemaran dari lingkungan baik pada saat pemotongan maupun selama pemasaran.

Pertumbuhan dan aktivitas mikroba dipengaruhi oleh faktor suhu penyimpanan, waktu, tersedianya oksigen dan kadar air daging (Hajrawati,2016). Mutu dan keamanan daging ayam terutama dipengaruhi oleh kualitas mikrobiologisnya. Daging ayam bersifat perishable (mudah rusak) karena sangat rentan terkontaminasi oleh mikroorganisme pembusuk maupun mikroorganisme patogen. Kontaminasi oleh mikroorganisme patogen seperti Salmonella typhimurium, Escherichia coli, dan Listeria monocytogenes dapat menimbulkan penyakit bahkan menyebabkan kematian. Kualitas daging di swalayan juga dapat dipengaruhi oleh air pencucian daging dan proses penyimpanan pada show case dengan suhu $0-3^{0} \mathrm{C}$. Oleh karena, itu untuk menghindari masuknya mikroorganisme pada daging ayam perlu dilakukan penanganan sesuai dengan standar keamanan pangan (Badan Standarisasi Nasional).Hasil survei dari Balai Besar Veteriner Denpasar di beberapa swalayan di Bali tahun 2007 menunjukkanAngka Lempeng Total Bakteri (ALTB) daging ayam melebihi Standar Nasional Indonesia (Syahruddin, 2014).

\section{METODE PENELITIAN}

Adapun jenis penelitian ini adalah eksperimen penelitian laboratorium yang bertujuan untuk mengetahui pengaruh lama penyimpanan daging ayam broiler terhadap kualitasnya ditinjau dari kadar protein dan angka lempeng total bakteri. Penelitian ini dilaksanakan selama sembilan hari yakni tanggal 11-19 Desember 2017. Analisis sampel dilakukan dilaboratorium MIPA Fakultas Ilmu Tarbiyah dan Keguruan, IAIN Ambon dan Laboratorium Kimia Dasar Universitas Pattimura.

Rancangan yang digunakan dalam penelitian ini adalah Rancangan Acak Lengkap (RAL). Penggunaan rancangan acak lengkap ini atas pertimbangan bahwa faktor lingkungan dapat dihomogenkan, yaitudengan menggunakan 3 perlakuan yang terdiri atas lama penyimpanan 2 hari, lama penyimpanan 4 hari dan lama penyimpanan 6 hari dengan masing-masing simbol A1, A2, dan A3, dan jumlah ulangan sebanyak 3 ulangan, sehingga total unit penelitian adalah 9 unit. Adapun objek penelitian pada penelitian ini adalah kandungan kadar protein dan angka lempeng total bakteri pada daging perlakuan dengan lama waktu penyimpanan 2 hari, 4 hari dan 6 hari.

\section{Pengambilan Sampel Ayam Broiler}

Pengambilan sampel pada penelitian ini dilakukan di pasar tradisional kota Ambon yaitu berupa ayam broiler sebanyak 4 ekor kemudian dipotong dan dibersihkan selanjutnya dimasukan kedalam freezer atau lemari dengan lama waktu penyimpanan 2 hari, 4 hari dan 6 hari.

\section{Pembuatan Medium NA}

Cara pembuatan medium nutrient agar (NA) yaitu sebagai berikut: 
1. Timbang 20 gram media Nutrient Agar (NA) padat.

2. Ukur 1 liter $(1000 \mathrm{ml})$ aquades ke dalam gelas kimia.

3. Larutkan media NA padat yang sudah ditimbang ke dalam $1000 \mathrm{ml}$ aquades.

4. Larutkan dengan menggunakan hot plate hingga mendidih dan mengaduknya sampai homogen.

\section{Pengujian Kadar Protein}

1. Tahap Destruksi

Timbang 1 gram sampel yang telah dihaluskan. Masukan kedalam labu Kjeldahl 100 ml, kemudian pipet $10 \mathrm{ml}$ asam sulfat pekat masukkan kedalam labu Kjeldahl. Tambahkan katalisator (campuran selenium) untuk mempercepat destruksi. Kemudian labu Kjeldahl tersebut dipanaskan dimulai dengan api yang kecil setelah beberapa saat sedikit demi sedikit api dibesarkan sehingga suhu menjadi naik. Destruksi dapat dihentikan pada saat didapatkan larutan berwarna jernih kehijauan.

2. Tahap Destilasi

Hasil destruksi yang didapatkan kemudian didinginkan, setelah itu di encerkan dengan aquades sampai $100 \mathrm{ml}$. setelah homogen dan dingin dipipet sebanyak $5 \mathrm{ml}$, kemudian masukan kedalam labu destilasi. Tambahkan $10 \mathrm{ml}$ larutan natrium hidroksida 30\% melalui dinding dalam labu destilasi hingga terbentuk lapisan dibawah larutan asam. Labu destilat dipasang dan dihubungkan dengan kondensor, lalu ujung kondensor dibenamkan dalam cairan penampung. Uap dari cairan yang mendidih akan mengalir melalui kondensor menuju Erlenmeyer penampung. Erlenmeyer penampung diisi dengan $10 \mathrm{ml}$ larutan asam klorida 0,1 $\mathrm{N}$ yang telah ditetesi indikator metal merah. Selanjutnya cek hasil destilasi dengan kertas lakmus, jika hasil sudah tidak bersifat basa lagi maka penyulingan dihentikan.

3. Tahap Titrasi

Setelah proses destilasi, tahap selanjutnya adalah titrasi. Hasil destilasi yang ditampung dalam Erlenmeyer berisi asam klorida $0,1 \mathrm{~N}$ ditetesi indicator metal merah sebanyak 5 tetes langsung dititrasi dengan menggunakan larutan natrium hidroksida 0,1 N. Titik akhir titrasi ditandai dengan warna merah muda menjadi kuning, selanjutnya lakukan titrasi blanko. Perlakuan ini dilakukan sebanyak 3 kali untuk tiap sampel (Rosaini, 2015). Untuk menghitung kadar protein dengan menggunakan rumus Standar Nasional Indonesi:

$$
\% \text { Kadar Nitrogen }=\frac{(\mathrm{S}-\mathrm{B}) \times \mathrm{N} \text { HCL } \times 14}{\mathrm{w} \times 10} \times 100 \%
$$

Kadar Protein $(\%)=\%$ Kadar Nitrogen $x$ Faktor Konversi $(6,25)$

Keterangan:

$\mathrm{S}=$ Volume titran sampel

$\mathrm{B}=$ Volume titran

$\mathrm{N}=$ Normalitas 
$\mathrm{W}=$ Bobot sampel kering (gr) (SNI, 2006)

\section{Pengujian ALT Bakteri}

Untuk teknik pengujian angka lempeng total bakteri adalah sebagai berikut:

1. Semua perlatan terlebih dahulu dibersihkan dan disterilkan dalam autoclave pada suhu $121^{\circ} \mathrm{C}$ selama 15 menit dengan tekanan 1 atm.

2. Selanjutnya tahap pembuatan pengenceran $10^{-1}$ dilakukan dengan cara sampel ditimbang sebanyak 25 gram yang sudah dihaluskan kemudian di masukkan kedalam larutan fisiologis $225 \mathrm{ml}$, selanjutnya di buat pengenceran $10^{-2}$ dengan cara mengambil $1 \mathrm{ml}$ sampel pada pengenceran $10^{-1}$ kemudian dimasukkan dalam tabung reaksi yang berisi $9 \mathrm{ml}$ larutan pengencer, begitu selanjutnya hingga terbentuk pengenceran $10^{-3}, 10^{-4}, 10^{-5}$ dan $10^{-6}$

3. Sampel yang telah diencerkan sesuai dengan tingkat pengenceran diambil sebanyak 1 $\mathrm{ml}$, lalu dipipetkan ke dalam cawan petri yang telah diberi tanda sesuai dengan tingkat pengenceran, kemudian media agar steril pada suhu $\pm 40^{\circ} \mathrm{C}$ dituangkan sebanyak 10 $15 \mathrm{ml}$ kedalam cawan petri tersebut. Cawan petri diputar perlahan-lahan hingga campuran merata, setelah itu dibiarkan membeku.

4. Cawan petri yang sudah membeku dimasukkan kedalam inkubator dengan posisi terbalik selama 24 jam pada suhu $37^{\circ} \mathrm{C}$. Koloni bakteri yang tumbuh dapat dihitung dengan menggunakan colony counter. Cara menghitung koloni bakteri dari masingmasing cawan petri dengan menggunaka rumus

$$
\mathrm{N}=\frac{\sum \mathrm{C}}{(1 \times n 1)+(0,1 \times n 2) \times d}
$$

5. Tahap pelaksaanan di atas akan dilakukan pada penelitian daging ayam dengan lama penyimpanan yang berbeda yang akan diuji dengan melakukan prosedur kerja yang sama sesuai dengan urutan prosedur (Atma, 2016).

Data yang diperoleh dalam penelitian ini berupa kadar protein dalam satuan (\%) dan nilai angka lempeng total bakteri dalam satuan koloni/gram dianalisis secara deskriptif dan statistik inferensial. Data yang diperoleh dari hasil perhitungan total koloni bakteri dianalisis dengan menggunakan uji ANAVA berbantu SPSS versi 21 for windows.

Data yang diperoleh dalam penelitian ini berupa kadar protein dalam satuan (\%) dan nilai angka lempeng total bakteri dalam satuan koloni/gram dianalisis secara deskriptif dan statistik inferensial. Analisis deskriptif bertujuan untuk menggambarkan kadar protein dan angka lempeng total bakteri daging ayam broiler setelah perlakuan dalam bentuk histogram. Sedangakn statistik inferensial digunakan untuk mengetahui pengaruh lama penyimpanan daging ayam broiler terhadap kadar protein dan angka lempeng total bakteri dengan menggunakan uji ANAVA berbantu SPSS versi 20 for windows. 


\section{HASIL DAN PEMBAHASAN}

Ayam broiler merupakan salah satu sumber protein hewani yang banyak digemari oleh masyarakat karena dapat diolah menjadi aneka makanan dengan nilai gizi yang tinggi. Selain memiliki kandungan gizi yang tinggi, ayam broiler mudah diternakkan dan dijual bebas di pasar tradisional maupun di swalayan. Ada beberapa faktor yang dapat mempengaruhi kualitas daging ayam broiler, salah satunya adalah lama penyimpanan pada freezer. Data tentang angka lempeng total bakteri pada daging ayam broiler berdasarkan lama penyimpanan dapat dilihat pada Tabel 1 berikut.

Tabel 1. Nilai ALT Bakteri Daging Ayam Broiler Berdasarkan Perlakuan lama Penyimpanan pada Freezer

\begin{tabular}{|c|c|c|c|c|c|}
\hline \multirow[t]{2}{*}{ Perlakuan } & \multicolumn{3}{|c|}{ Ulangan $\left(. . X 10^{6} \mathrm{kol} / \mathrm{gr}\right)$} & \multirow[t]{2}{*}{ Jumlah } & \multirow[t]{2}{*}{ Rerata $\left(. . \times 10^{6} \mathrm{kol} / \mathrm{gr}\right)$} \\
\hline & 1 & 2 & 3 & & \\
\hline 2 hari & 24,6 & 27,2 & 27,85 & 79,65 & 26,55 \\
\hline 4 hari & 16,16 & 15,83 & 11,1 & 43,09 & 14,36 \\
\hline 6 hari & 15,3 & 5,025 & 14,7 & 35,025 & 11,67 \\
\hline
\end{tabular}

Berdasarkan Tabel 1 tersebut, terlihat bahwa rerata nilai angka lempeng total bakteri dari setiap kali penyimpanan ditemukan kandungan bakteri pada daging ayam broiler dengan penyimpanan yang berbeda. Kandungan bakteri tertinggi ditemukan pada penyimpanan hari ke-2, yaitu dengan rerata ALT bakteri adalah $26,55 \times 10^{6} \mathrm{kol} / \mathrm{gr}$, pada penyimpanan hari ke-4 yaitu dengan rerata ALT bakteri $14,36 \times 10^{6} \mathrm{kol} / \mathrm{gr}$ dan pada penyimpanan hari ke-6 yaitu dengan rerata ALT bakteri adalah 11,67x10 6 kol/gr. Secara umum, rerata jumlah bakteri pada masa penyimpanan 2, 4, dan 6 hari mengalami penurunan. Namun, jumlah koloni bakteri tersebut masih melebihi batas Standar Nasional Indonesia, sehingga daging ayam broiler tersebut tidak layak untuk dikonsumsi, kecuali dilakukan proses pengolahan yang baik dan benar.

Daging ayam broiler yang disimpan dalam freezer selama 2, 4, dan 6 hari mengandung bakteri yang semakin lama disimpan maka semakin menurun jumlah bakterinya. Kandungan bakteri terrendah ditemukan pada daging ayam broiler yang disimpan di dalam freezer selama 6 hari dengan rerata ALT bakteri adalah 11,67x 10 kol/gr. Artinya bahwa dalam setiap 1 gram sampel daging ayam yang diuji terkandung 11.067.000 koloni bakteri. Berdasarkan hasil pengamatan, menunjukkan bahwa semakin lama daging ayam broiler disimpan di dalam freezer, maka kandungan bakterinya semakin rendah menurun. Untuk menjawab hipotesis diterima atau di tolak maka data penelitian yang telah ditransformasikan dan dianalisis dengan menggunakan uji anava berbantu SPPS versi 21. Dari uji anava pada Tabel 2 menunjukan bahwa terdapat pengaruh lama penyimpanan daging ayam broiler terhadap angka lempeng total bakteri, yang dapat dilihat pada Tabel 2 berikut ini.

BIOLOGI SEL (YOL 8 NO 1 EDISI JAN-JUN 2019 ISSN 2252-858X/E-ISSN 2541-1225) PAGE 52 
Tabel 2. Analisis Sidik Ragam

\begin{tabular}{|l|l|c|c|c|c|c|}
\hline & & Sum of Squares & df & Mean Square & F & Sig. \\
\hline ALT Bakteri & Between Groups & 377,300 & 2 & 188,650 & 12,748 & 0,007 \\
\cline { 2 - 7 } & Within Groups & 88,790 & 6 & 14,798 & & \\
\cline { 2 - 8 } & Total & 466,091 & 8 & & & \\
\hline
\end{tabular}

Hasil pengujian pada perlakuan menunjukan nilai hasil signifikansi $(0,007)<$ Taraf signifikan $(0,05)$. Hal ini berarti, uji anava menunjukan bahwa lama penyimpanan berpengaruh terhadap kandungan angka lempeng total bakteri pada daging ayam broiler atau $\mathrm{H} 0$ ditolak dan $\mathrm{H} 1$ diterima dengan besar pengaruh 12,7 \%. Dan untuk mengetahui perbedaan yang signifikan tiap perlakuan maka dilakukan uji lanjut Homogeneous Subsets dengan menggunakan software SPSS. Hasil uji lanjut Homogeneous Subsets dapat dilihat pada Tabel 3 berikut ini.

Tabel 3. Uji lanjut Homogeneous Subsets

\begin{tabular}{|l|c|c|c|c|}
\hline \multirow{3}{*}{ Duncan $^{\mathrm{a}}$} & Lama_Penyimpanan & \multirow{2}{*}{$\mathrm{N}$} & \multicolumn{2}{|c|}{ Subset for alpha $=0.05$} \\
\cline { 3 - 5 } & & & 1 & 2 \\
\cline { 2 - 5 } & 6 & 3 & 11.6667 & \\
\cline { 2 - 5 } & 4 & 3 & 14.3633 & \\
\cline { 2 - 5 } & 2 & 3 & & 26.5500 \\
\hline
\end{tabular}

Berdasarkan Tabel 3 tersebut, terlihat bahwa kolom subset 1 terdapat dua nilai dari variabel lama penyimpanan 6 dan 4 hari dan kolom subset 2 hanya terdapat satu nilai dari variabel lama penyimpanan 2 hari. Hal ini menunjukkan rerata penyimpanan 6 dan 4 hari tidak memiliki perbedaan yang signifikan namun keduanya memiliki perbedaan yang signifikan terhadap lama penyimpanan 2 hari. Selain menghitung jumlah bakteri pada daging ayam broiler berdasarkan lama penyimpanan di dalam freezer, dalam penelitian ini dilakukan perhitungan jumlah protein pada daging ayam broiler, dengan asumsi bahwa bakteri akan tumbuh dengan baik pada bahan organik dengan menggunakan bahan tersebut sebagai sumber nutrisi. Data tentang kandungan protein daging ayam broiler berdasarkan lama penyimpanan dapat dilihat pada Tabel 4. berikut.

Tabel 4. Nilai kadar protein Daging Ayam Broiler Berdasarkan Perlakuan lama

Penyimpanan pada Freezer

\begin{tabular}{|c|c|c|c|c|c|}
\hline \multirow{2}{*}{ Perlakuan } & \multicolumn{3}{|c|}{ Ulangan } & \multirow{2}{*}{ Jumlah } & Rerata(\%) \\
\cline { 2 - 4 } & 1 & 2 & 3 & & 20,46 \\
\hline 2 Hari & 20,58 & 20,45 & 20,35 & 61,38 & 20,97 \\
\hline 4 Hari & 21,04 & 20,85 & 21,04 & 62,93 & 22,44 \\
\hline 6 Hari & 23,13 & 22,65 & 21,56 & 67,34 & \\
\hline
\end{tabular}

Berdasarkan Tabel 4. tersebut ditemukan bahwa kadar protein pada penyimpanan hari ke-2 yaitu dengan rerata nilai kadar protein 20,46\%, kadar protein pada penyimpanan hari ke-4 yaitu dengan rerata nilai kadar protein $20,97 \%$, dan kadar protein tertinggi ditemukan pada lama penyimpanan 6 hari yaitu dengan rerata nilai kadar protein 22,44\%,

BIOLOGI SEL (YOL 8 NO 1 EDISI JAN-JUN 2019 ISSN 2252-858X/E-ISSN 2541-1225) PAGE 53 
hal ini disebabkan karena jumlah bakteri yang menggunakan protein daging ayam semakin sedikit, sehingga menyebabkan kadar protein pada daging ayam broiler. tidak mengalami penurunan yang begitu drastis (Rijal. M, 2016).

Untuk menjawab hipotesis diterima atau di tolak maka data penelitian yang telah ditransformasikan dan dianalisis dengan menggunakan uji anava berbantu SPPS versi 21. Dari uji anava pada Tabel 5 menunjukan bahwa ada pengaruh lama penyimpanan daging ayam broiler terhadap kadar protein.

Tabel 5. Analisis Sidik Ragam Satu Arah

\begin{tabular}{|c|l|r|r|r|r|c|}
\hline & & Sum of Squares & Df & $\begin{array}{c}\text { Mean } \\
\text { Square }\end{array}$ & F & Sig. \\
\hline Kadar_Protein & $\begin{array}{l}\text { Between } \\
\text { Groups }\end{array}$ & 6,375 & 2 & 3,187 & $\begin{array}{r}14,21 \\
7\end{array}$ & 0,005 \\
\cline { 2 - 7 } & $\begin{array}{l}\text { Within } \\
\text { Groups }\end{array}$ & 1,345 & 6 & 0,224 & & \\
\cline { 2 - 7 } & Total & 7,720 & 8 & & & \\
\hline
\end{tabular}

Hasil pengujian pada perlakuan menunjukan nilai hasil signifikansi $(0,005)<$ taraf signifikan $(0,05)$. Hal ini berarti, uji anava menunjukan bahwa lama penyimpanan berpengaruh terhadap kandungan kadar protein daging ayam broiler atau $\mathrm{H} 0$ ditolak dan H1 diterima dengan besar pengaruh 14,2 \%. Dan untuk mengetahui perbedaan yang signifikan tiap perlakuan maka dilanjutkan dengan uji Homogeneous Subsets. Hasil uji lanjut Homogeneous Subsets dapat dilihat pada Tabel 6 berikut.

Tabel 6 Uji lanjut Homogeneous Subsets

\begin{tabular}{|l|c|c|c|c|}
\hline \multirow{4}{*}{} & Lama_Penyimpanan & \multirow{2}{*}{$\mathrm{N}$} & \multicolumn{2}{|c|}{ Subset for alpha $=0.05$} \\
\cline { 3 - 5 } & & & 1 & 2 \\
\hline Duncan $^{\mathrm{a}}$ & 2 & 3 & 20.4600 & \\
\cline { 2 - 5 } & 4 & 3 & 20.9767 & \\
\cline { 2 - 5 } & 6 & 3 & & 22.4467 \\
\cline { 2 - 5 } & Sig. & & .230 & 1.000 \\
\hline
\end{tabular}

Dari Tabel 6 tersebut, terlihat bahwa kolom subset 1 terdapat dua nilai dari variabel lama penyimpanan 2 dan 4 hari dan kolom subset 2 hanya terdapat satu nilai dari variabel lama penyimpanan 6 hari. Hal ini menunjukkan rerata penyimpanan 2 dan 4 hari tidak memiliki perbedaan yang signifikan namun keduanya memiliki perbedaan yang signifikan terhadap lama penyimpanan 6 hari.

Berdasarkan hasil pengujian secara deskriptif, angka lempeng total bakteri pada daging ayam broiler yang disimpanan selama 2, 4 dan 6 hari menunjukkan penyimpanan diatas rata-rata, yaitu penyimpanan yang jumlah bakterinya sudah melebihi Standar Nasional Indonesia tentang Spesifikasi Persyaratan Batas Maksimum Cemaran Mikroba pada pangan yaitu $1 \times 10^{6} \mathrm{kol} / \mathrm{gr}$. Selama penyimpanan itu dapat terlihat bahwa daging sudah tidak empuk, saat dihaluskan tekstur daging mengeras, dan warna daging berwarna pucat yang disebabkan oleh adanya aktivitas pertumbuhan mikroba. Pada penyimpanan 6 hari terlihat jumlah total koloni bakteri mengalami penurunan bila dibandingkan dengan lama penyimpanan 2 dan 4 hari.

BIOLOGI SEL (YOL 8 NO 1 EDISI JAN-JUN 2019 ISSN 2252-858X/E-ISSN 2541-1225) PAGE 54 
Saat penyimpanan daging ayam selama 2 hari daging masih telihat segar, teksturnya mulai sedikit mengeras, aroma dan warna pada daging sedikit pucat karena penyimpanan pada suhu dingin. Pada saat dilakukan pengujian terhadap pertumbuhan bakteri, jumlah bakteri yang tumbuh pada media NA ditumbuhi bakteri yang cukup tinggi yaitu dengan rerata bakteri sebesar 26,55 x 106 $/$ gr daging ayam. Hal ini, disebabkan karena terjadi kontaminasi permukaan daging.

Kontaminasi dapat terjadi selama tahap proses meliputi penyembelihan, memasukan air mendidih, pencabutan bulu, eviserasi, mencuci dan mendinginkan bahkan sampai penyimpanan. Permukaan daging segar yang berhubungan dengan udara akan menguntungkan bagi bakteri aerobik (tumbuh tanpa memerlukan oksigen). Selain itu, bakteri bisa tumbuh pada suhu tertentu dan akan mati pada suhu tertentu, serta kelembapan yang semakin tinggi atau aktivitas air, oksigen juga mempengaruhi pertumbuhan mikroorganisme (Sangadji, 2013).

Menurut Nyoman (2015), daging memang merupakan media yang ideal bagi perkembangbiakan mikroorganisme (baik mikroorganisme perusak maupun pembusuk). Hal ini disebabkan kadar air daging yang tinggi (68-75\%), kaya akan zat yang mengandung nitrogen, mengandung sejumlah zat yang dapat difermentasikan, kaya akan mineral, dan mempunyai $\mathrm{pH}$ yang menguntungkan bagi pertumbuhan mikroorganisme (5,3-6,5) (Miwada, 2015). Sedangkan menurut Cicilia Takasari (2008), daging mengandung zat gizi yang tinggi terutama proteinnya dengan komposisi asam amino yang seimbang dan bermanfaat bagi tubuh manusia. Kandungan gizi yang tinggi menyebabkan daging mempunyai sifat mudah rusak (perishable) karena mikrooganisme dapat tumbuh dan berkembangbiak di dalamnya. Salah satu mikroorganisme perusak yang terkandung di dalam daging ayam broiler adalah bakteri.

Pada Penyimpanan 4 hari daging ayam sudah telihat kualitas dari daging mulai menurun, daging ayam waktu dihaluskansudah sedikit mengeras, aroma tidak segar. Jumlah koloni yang tumbuh semakin berkurang dibandingkan penyimpanan 2 hari, untuk penyimpanan 4 hari diperoleh nilai rata-rata jumlah koloni sebanyak 14,36 x 10\%/gr daging ayam.Penyimpan daging ayam selama 4 hari terdapat perubahan dari segi kualitas daging. Serta pertumbuhan bakteri, penyimpanan daging dalam pendingin pada suhu $3^{\circ} \mathrm{C}$ akan membunuh pertumbuhan mikroorganisme, dan penyimpanan pada suhu dingin dapat mengurangi kualitas daging, keempukan dan warna daging. Temperatur dibawah kira-kira $3^{0} \mathrm{C}$ dapat menghambat pertumbuhan mikroorganisme perusak atau pembusuk dan mencegah hampir semua bakteri patogen. Sedangkan pada penyimpanan 6 hari pertumbuhan bakteri dalam hal ini jumlah koloni jauh lebih sedikit dibandingkan dengan 2 dan 4 hari. Untuk penyimpanan ini diketahui kualitas dari daging ayam, makin lama penyimpanan makin sedikit jumlah pertumbuhan jumlah koloni bakteri, suhu yang dipakai untuk tahap penyimpanan adalah suhu $3^{0} \mathrm{C}$, pada suhu ini dapat mematikan 
bakteri disamping itu kualitas dari daging sapi tersebut menurun, tapi masih layak dikonsumsi oleh manusia (Atma, 2016).

Selain menghitung jumlah bakteri pada daging ayam broiler berdasarkan lama penyimpanan di dalam freezer, dalam penelitian ini dilakukan perhitungan jumlah protein pada daging ayam broiler, dengan asumsi bahwa bakteri akan tumbuh dengan baik pada bahan organik dengan menggunakan bahan tersebut sebagai sumber nutrisi. Berdasarkan Tabel 4 dapat diketahui bahwa, pengukuran nilai kadar protein daging ayam broiler berdasarkan perlakuan lama penyimpanan 2 hari, 4 hari hingga 6 hari, tidak mengalami penurunan. Hal ini disebabkan karena berkurangnya konsumsi protein oleh bakteri selama masa penyimpanan, hal ini dapat dilihat selama penyimpanan jumlah bakteri semakin berkurang.

Berdasarkan pengukuran nilai kadar protein daging ayam broiler pada perlakuan lama penyimpanan 2 hari, 4 hari hingga 6 hari, tidak mengalami penurunan. Hal ini disebabkan karena berkurangnya konsumsi protein oleh bakteri selama masa penyimpanan, hal ini dapat dilihat semakin lama masa simpan daging ayam broiler didalam suhu freezer maka semakin berkurang jumlah bakterinya. Hal ini juga senada dengan Anica Rosalina yang menyatakan bahwa penurunan suhu pada titik beku bahan dimaksudkan untuk menghilangkan dengan cepat kalor yang terdapat pada produk pangan. Penurunan suhu mengakibatkan laju pertumbuhan mikroorganisme terhambat, menghambat reaksi kimia dalam bahan pangan. Dengan demikian, proses penurunan suhu pada titik beku bahan dilakukan semakin cepat semakin baik untuk menjaga mutu bahan yang akan dibekukan (Rosalina, 2010).

\section{KESIMPULAN}

Kesimpulan dari penelitian ini: (1) Terdapat pengaruh lama penyimpanan daging ayam broiler terhadap kadar protein dan angka lempeng total bakteri. (2) Besar pengaruh lama penyimpanan daging ayam broiler terhadap kadar protein adalah 14,2\% sedangkan besar pengaruh lama penyimpanan daging ayam broiler terhadap angka lempeng total bakteri adalah $12,7 \%$.

\section{DAFTAR PUSTAKA}

Adiningsih, Melani Wahyu. (2009). Aspek Mikrobiologis Daging Ayam Beku Yang Dilalulintaskan Melalui Pelabuhan Penyeberangan Merak. Bogor.

Alwin K. Y. Wowor, dkk. (2014). Lama penyimpanan pada suhu dingin daging broiler yang diberi air perasan jeruk kasturi (Citrus madurensis lour). Jurnal zootek (“zootek journal”) Vol 34 No 2: 148 - 158 .

Atma, Yoni. (2016). Angka Lempeng Total (Alt), Angka Paling Mungkin (Apm) Dan Total Kapang Khamir Sebagai Metode Analisis Sederhana Untuk Menentukan 
Standar Mikrobiologi Pangan Olahan Posdaya. Jurnal Teknologi Volume 8 No.

2 Juli 2016, Univeritas Muhammadiyah Jakarta

Departemen Kesehatan RI. (1996). Daftar Komposisi Bahan Makanan, Brhatara: Jakarta. Hajrawati dkk. (2016). Kualitas Fisik, Mikrobiologis Dan Organoleptik Daging Ayam Broiler Pada Pasar Tradisional Dibogor. Jurnal Ilmu Produksi Dan Teknologi Hasil Peternakan. Vol. 04 No. 3 Oktober 2016. Departemen Produksi dan Teknologi Peternakan, Fakultas Peternakan, IPB.

Hanafiah, Kemas Ali. (2016). Rancangan Percobaan:Teori dan Aplikasi. PT Raja Grafindo Persada. Jakarta.

Harjanto, Danni. (2006). Kualitas Kimia Daging Dada Ayam Broiler Yang Pakannya Ditambahkan Campuran Minyak. Skripsi Ikan Kaya Asam Lemak Omega-3”, Skripsi. Program Studi Teknologi Hasil Ternak, Fakultas Peternakan, Institut Pertanian Bogor.

Kusumanigrum. (2013). Penurunan Total Bakteri Daging Ayam Dengan Perlakuan Perendaman Infusa Daun Salam (Syzygium Polyanthum). Jurnal MIPA, Semarang.

Magfirah Syahruddin, dkk. (2014). Angka Lempeng Total Bakteri pada Broiler Asal Swalayan di Denpasar dan Kabupaten Badung. Indonesia Medicus Veterinus 2014 3(2) : 107-111 ISSN : 2301-7848 107.

Matulessy, Dellen Naomi. (2011). Analisis Mikrobiologis Karkas Ayam Broiler Bekuyang Beredar Di Pasar Tradisional Halmahera Utara. Jurnal Agroforestri, Volume VI Nomor 1 Maret 2011.

Miwada, I Nyoman Sumerta. (2015). Teknologi Pembekuan Daging: Bentuk Selamat Dari Pembusukan. Karya Ilmiah, Fakultas Peternakan Universitas Udayana, Denpasar.

Pestariati. (2000). Pengaruh Lama Penyimpanan Daging Ayam Pada Suhu Refrigerator Terhadap Jumlah Kuman, Salmonella sp, Kadar Protein dan Derajat Keasaman” Tesis, Program Pasca sarjana Universitas Airlangga, Surabaya.

Rijal, M. (2016). PENGOLAHAN DAN PENINGKATAN KADAR PROTEIN FISH NUGGET BERBAHAN DASAR LIMBAH IKAN DENGAN PEMBERIAN EKSTRAK KULIT NANAS. Biosel: Biology Science and Education, 5(1), 8492.

Risnajati, Dede. (2010). Pengaruh Lama PenyimpanandalamLemariEsterhadap PH, Dayalkat Air, dan Susut Masak Karkas Broiler yang Dikemas Plastik Polyethylen. Jurnal Ilmiah Ilmu-Ilmu Peternakan, Vol. XIII, No. 6.

Henni Rosaini dkk. (2015). Penetapan Kadar Protein secara Kjeldahl Beberapa Makanan Olahan Kerang Remis (Corbiculla moltkiana Prime.) Dari Danau Singkarak. Jurnal Farmasi Higea, Vol. 7, No. 2. 
Rosalina ,Anica G. (2010). Kajian Energi Pembekuan Daging Sapi Menggunakan Mesin Pembeku Tipe Lempeng Sentuh Dengan Suhu Pembekuan Berubah. Skripsi. Departemen Teknik Pertanian Fakultas Teknologi Pertanian, Institut Pertanian Bogor.

Sangadji, Insun. (2013). Lama Penyimpanan Daging Sapi Terhadap ALT Bakteri. Jurnal Biology Science \& Education Vol 5 No 1 IAIN Ambon.

Soeparno. (2011). Ilmu Nutrisi dan Gizi Daging. Gadjah Mada University Press: Yogyakarta.

Suradi, Kusmajadi. (2006). Perubahan Sifat Fisik Daging Ayam Broiler Post Mortem Selama Penyimpanan Temperatur Ruang(Change of Physical Characteristics of Broiler ChickenMeat Post Mortem During Room Temperature Storage. Jurnal Ilmu Ternak, vol. 6 no. 1, 23 - 27.

Sholaikah, Maya Ina. (2015). Profil Protein Jaringan Otot Daging Ayam Potong PraPenyembelihan Electrical Stunning Dan Non Electrical Stunning. Skripsi, Fakultas Sains Dan Teknologi UIN Syarif Hidayatullah Jakarta,

Standar Nasioal Indonesia (SNI). NO.7388:2009. Batas Maksimum Cemaran Mikroba Dalam Pangan.ICS 67.220.20. Badan Standarisasi Nasional

Standar Nasional Indonesia 01-2354.4-2006. Penentuan Kadar Protein Metode Total Nitrogen Pada Produk Pangan. Badan Standarisasi Indonesia.

Takasari, Cicilia. (2008). Kualitas Mikrobiologis Daging Sapi Segar Dengan Penambahan Bakteriosin Dari Lactobacillus sp. Galur SCG 1223 Yang Diisolasi Dari Susu Sapi. Skripsi, Program Studi Teknologi Hasil Ternak, Fakultas Pertanian, IPB.

Yuanisa, Yefirma Yani. (2005). Kualitas mikrobiologi karkas ayam broiler padaberbagai lama postmortem. Skripsi. Program Studi Teknologi HasilTernak, Fakultas Peternakan, Institut Pertanian Bogor.

Yulian, Nadia Eka. (2017). Studi Infeksi Koksidia Pada Ayam Petelur (Gallus gallus) Strain LohmanJantan Di Peternakan Mandiri Kelurahan Segalamider, Kecamatan Tanjung Karang Barat, Kota Bandar Lampug. Skripsi. Fakultas Matematika Dan Ilmu Pengetahuan Alam Universitas Lampung, Bandar Lampung.

Warsianti. (2008). Pengaruh Lama Penyimpanan Daging Ayam Pada Suhu Refrigerator Terhadap Jumlah Total Kuman, Salmonella Sp, Kadar Protein Dan Derajat Keasaman. Diakses darihttp://warsianti.blogspot.co.id/2008/02/pengaruh-lamapenyimpanan-daging-ayam.html, pada tanggal 10 Oktober pukul 20.00. 